\title{
A CASE OF TEACHING MODERN LATVIAN
}

\section{Ërika SAUSVERDE \\ Vilnius University}

To learn the new words was one thing, to learn their meanings was another. It sounds maybe a bit paradoxical, but it is easy. One learns the words first as names and that takes nothing but a good memory. But these names are not neutral, they are covered by the centuries of lava of human knowledge, feelings, experiences and values. To learn a new language becomes in that way a pervasive travel into a different understanding of the world and life itself.

\section{Theodor Kallifatides}

In December 1986 after finishing PhD studies in historical linguistics in St. Petersburg I started to work at Vilnius University. To my surprise my main task became the teaching of Latvian to numerous students studying Lithuanian Philology as their main subject. Not Swedish or Gothic or other old Germanic Languages - my specialization, but my mother tongue. Simultaneously I myself was strenuously learning Lithuanian - the thought that in a month I should deliver a course on Old Germanic Languages in Lithuanian, about which I then knew so little, spurred me on as nothing else $-\mathrm{a}$ few classes of Lithuanian which I attended in St. Petersburg when we took our time reading some weird and wonderful Lithuanian fairy tales were left far behind - in a month I should tell students in Lithuanian about peripeteias of visi- and ostrogoths, Codex Argenteus, runic inscriptions etc. ${ }^{1}$ Maybe it was a blessing that I was not then acquainted with the modern methodology of language teaching, and was groping my way, choosing instinctively, feeling on a hunch which way of learning and teaching would be the best. I was glad at least to realize which way of learning and teaching I did not like and could reject methods and sources which I would not like to use learning languages myself. Curiously enough, my knowledge of Lithuanian structure was based on 11 chapters of Alfred Senn's book Kleine Litauische Sprachlehre, published in Heidelberg in 1929, kindly lent to me by my advisor prof. Leonard Herzenberg. My first two sentences in Lithuanian

1 The difference between these two live Baltic Languages is much greater than, e.g., between the Scandinavian ones which have stayed close to each other (by which I mean Swedish, Norwegian and Danish) - the structure of Lithuanian and Latvian is very similar and it is possible to recognize much of vocabulary, but the difference is too great to comprehend one other, hence you must learn. To some extent, the difference could be compared to that of Swedish and German. 
which I coincidentally read in Senn's book when I opened it for the first time were: Alus yra skanus (,Beer is tasty') and Lietuvos prezidentas gyventu Vilniuje, jeigu tas miestas nebütų lenku ('the President of Lithuania would have lived in Vilnius, if that city had not been Polish')2. Those phrases captured my heart, plus I simply liked the structure of the book, the clear exposition of grammar, which I prefered to the then popular and available textbook of Lithuanian. With regard lexicon I simply tried to write the texts of my lectures (including jokes) and learned them by heart (I can just imagine how students were entertained listening to me). Similarly I was searching for my own method of teaching languages. I did not like the textbooks published on either side of the Iron Curtain that were then available - it wasn't the ideology that was a barrier for me, but the "woodenness" of their language.

No method of teaching languages is bad or "not modern" if it works. A brief history of language teaching shows that many new ideas are revised old ones and are not particulary new, as demonstrated by Kelly (1969), Howatt (1984) and others. According to Richards and Rodgers (1986: 1), today's controversies reflect contemporary responses to questions that have been asked often throughout the history of language teaching. As indicateded by Eloeva, numerous reviews of the subject (even the most brief ones) show that, in spite of the impressive diversity of methods and approaches to language teaching, certain basic ideas about the specifics of connection and interplay between language and cognition, language and mind are repeated, reinterpreted, rejected and used again on theoretical as well as empirical levels (this being true since the 19th century) (Eloeva 2009). A detailed analysis of the different methods can be found in Richards and Rodgers (1986). This gives an excellent detailed account of major twentieth-century trends in language teaching. If we were to make a brief summary of some more popular teaching methods, one of the most well-liked in XX century was The Direct Method, which refers to the most widely known of natural methods. In practice it stood for the following principles and procedures:

1. Classroom instruction was conducted exclusively in the target language.

2. Only everyday vocabulary and sentences were taught.

3. Oral communication skills were built up in a carefully graded progression organized around question-and-answer exchanges between teachers and students in small, intensive classes.

4. Grammar was taught inductively.

5. New teaching points were introduced orally.

2 That phrase of course could not be pronounced out loud in those Soviet times as one could easily find oneself in prison. 
6. Concrete vocabulary was taught through demonstration, objects, and pictures; abstract vocabulary was taught by association of ideas.

7. Both speech and listening comprehension were taught.

8. Correct pronunciation and grammar were emphasized.

(Richards and Rodgers 1986: 9-10)

These principles are seen in the following guidelines for teaching oral language, which were followed in Berlitz schools:

Never translate: demonstrate

Never explain: act

Never make a speech: ask questions

Never imitate mistakes: correct

Never speak with single words: use sentences

Never speak too much: make students speak much

Never use the book: use your lesson plan

Never jump around: follow your plan

Never go too fast: keep the pace of the student

Never speak too slowly: speak normally

Never speak too quickly: speak naturally

Never speak too loudly: speak naturally

Never be impatient: take it easy

(Titone 1968: 100-101, cited in Richards and Rodgers 1986: 9-10)

The Direct Method was quite successful in private language schools, but was gradually modified into versions that combined some Direct Method techniques with more controlled grammar-based activities (Ibid: 11).

The other popular language teaching methodologies include such methods as e.g. Grammar-translation; Audio-lingual; The structural approach; Total Physical Response (TPR); Communicative language teaching (CLT); The Silent Way; Community Language Learning; Immersion; Task-based language learning; The Natural Approach; The Lexical Syllabus and so forth (see e.g. Richards and Rodgers 1986, where particular language teaching methods and philosophies are discussed and analysed).

As Richards and Rodgers precisely notice, the survey of language methods raised the questions that prompted innovations and new directions in language teaching in the past, but they are still relevant nowadays:

1. What should the goals of language teaching be?

2. Should a language course try to teach conversational proficiency, reading, translation, or some other skill?

3. What is the basic nature of language, and how will this affect teaching method? 
4. What are the principles for the selection of language content in language teaching?

5. What principles of organization, sequencing, and presentation best facilitate learning?

6. What should the role of the native language be?

7. What processes do learners use in mastering a language, and can these be incorporated into a method?

8. What teaching techniques and activities work best and under what circumstances? (Ibid: 12).

Today in the 21st century so-called communicative language teaching (CLT) has become a buzzword in discussions of the practice and theory of second and foreign language teaching (see Savignon 2007). Though CLT can be seen to derive from a multidisciplinary perspective that includes, at least, linguistics, psychology, philosophy, sociology, and educational research (Ibid: 209) and to incorporate dialogue in all possible meanings as one of its fundamentals (Bakhtin's Dialogue of cultures included), it seems there is a big gap between CLT as an approach and its implementation. Nowadays the world is filled with numerous textbooks based on the principles of the CLT approach full with plenty of dialogues like "at the station", "at the post office" and so forth with plain and primitive texts where a normal developed person just loses his/her identity (of course, there are exceptions). What is the main thing you actually need when you want to send a parcel? - Money. You can be tired and hardly mumble a word, but if you have money you will manage it. But if you approach, for example, a lady in the post-office e. g. in Greece speaking in the language of Kavafis and Seferis you have a chance to send the parcel even without money. ${ }^{3}$ In this context the understanding of Bakhtin's idea of the dialogicity of speech does not dissappear, but still I agree with idea that dialogue should be born within the free communication of learners who are taught to produce a monologue (Eloeva 2009).

Recognition of the complexity and diversity of language learning contexts has led some to suggest that we have moved 'beyond methods' to a postmethod condition (Kumaravadivelu 2002, cited in Savignon, 2007: 218). Nowadays armed by different kinds of knowledge about language teaching looking back at the dawn of my activity I can formulate that my instinctively chosen method was based on mixed principles from different methodologies, including AudioLingual and others. The materials I used were "just" good texts. In the case of the Latvian course for beginners these comprised plenty of poetry - mostly

3 This example is from Prof. Fatima Eloeva, whose teaching methods show extraordinary results with regard language aquisition over a relatively short time. 


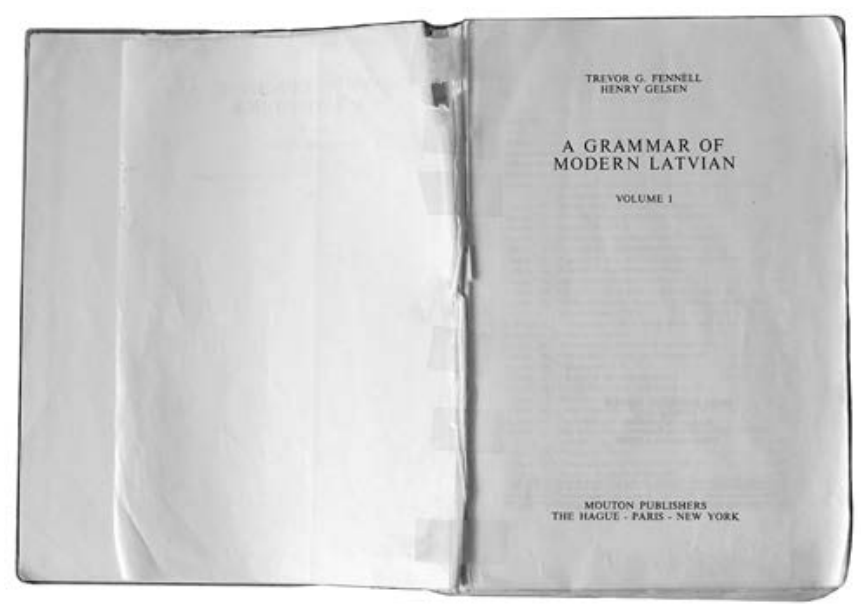

Figure 1. The copy of the book A Grammar of Modern Latvian by Trevor G. Fennell and Henry Gelsen (1980) used as a class manual for more than 20 years

wonderful children's poetry by Jānis Baltvilks - and other hitherto unadopted texts, whether in the original, such as Latvian fairy tales, or translations, e.g. Winnie the Pooh. ${ }^{4}$ I was happy to find at the University Library A Grammar of Modern Latvian by Trevor G. Fennell and Henry Gelsen (1980). I liked its approach - the clear exposition of grammar with hundreds of drills to translate. ${ }^{5}$ Such a method, i.e. of constructing lectures around good texts along with plenty of oral (grammar) drills ${ }^{6}$, I also successfully used in my Swedish classes, where the intensity of the course allowed us to rather rapidly move to the marvellous poetry of Tomas Tranströmer and related discussions. ${ }^{7}$ I completely agree with the idea that such a method concentrates on helping the learner to move rather speedily from the phase of interlanguage to the target language or in the ideal case (using certain mnemonic techniques) to avoid the phase of interlanguage.

4 A. A. Milne's Winnie the Pooh in a wonderful translation of Vizma Belševica in Latvia has become folklore - it is often quoted by people (some years ago I heard it three times during one week - by 2 politicians and a basket coach).

5 When meeting former students years later they still quote me Mums ir vins pagrabā ("We have wine in the cellar" - one of thousand sentences/drills in Fennell/Gelsen's book) along with numerous poems.

6 Of course, accompanied by hundreds of different sources and techniques.

7 It was fascinating to hear that the well known Swedish writer Theodor Kallifatides, who came to Sweden at the age of 25, learned Swedish reading August Strindberg. 


\section{References}

Eloeva, Fatima. 2009. Language teaching - monologue or dialogue? Proceedings of 9th International Conference on Greek Linguistics. 29 October 2009-31 October 2009 Chicago, Illinois, USA.

Fennell, Trevor G., Henry Gelsen. 1980.

A Grammar of Modern Latvian. Volumes 1-3. De Gruyter Mouton.

Howatt, Anthony P. R. 1984.

Kelly, Louis G. 1969.

A History of English Language Teaching. Oxford: Oxford University Press.

25 Centuries of Language Teaching; an inquiry into the science, art, and development of language teaching methodology, 500 B.C.1969. Rowley, Mass.: Newbury House Publishers.

Kumaravadivelu, B. 2002. Beyond Methods: Macrostrategies for Language Teaching. New Haven and London: Yale University Press.

Richards, Jack C., Theodore

S. Rodgers. 1986.

Approaches and Methods in Language Teaching. A description and analyses. Cambridge Language Teaching Library. Cambridge: Cambridge University Press.

Savignon, Sandra J. 2007. Beyond communicative language teaching: What's ahead? Journal of Pragmatics 39 (2007). 207-220.

Titone, Renzo. 1968.

Teaching Foreign Languages: An Historical Sketch. Washington, D.C.: Georgetown University Press.

Ërika Sausverde

Skandinavistikos centras

Filologijos fakultetas

Vilniaus Universitetas

Universiteto g. 5, LT-01513 Vilnius, Lietuva

erika.sausverde@flf.vu.lt

\section{KOPSAVILKUMS}

\section{Mūsdienu latviešu valodas mācǐšanas gadījums}

\section{Ērika SAUSVERDE}

Neskaitāmi valodu mācību tēmas pārskati liecina, ka, neraugoties uz metožu un pieeju iespaidīgo daudzveidību, dažas pamatidejas tiek daudzkārt atkārtotas un interpretētas. Valodu apguves kontekstu sarežğìitîbas un daudzveidības atzǐšana dažiem autoriem liek domāt, ka esam nonākuši līdz „postmetodes“ stāvoklim (Kumaravadivelu 2002; Savignon 2007). Šksiet, ka pastāv liela atškirīiba starp CLT (komunikatīvā valodas mācīšana - viena no populārākajām metodēm mūsdienās) kā pieeju un tās īstenošanu. Šajā rakstā tiek uzskatīts, ka dialogam, kas ir viens no CLT pamatiem, vajadzētu veidoties brīvā saziņā starp izglītojamajiem, kuriem māca veidot monologu. Lekciju konstruēšana ap labiem tekstiem kopā ar daudziem (gramatikas) vingrinājumiem ir metode, kas var palīdzēt izglītojamajam diezgan ātri pāriet no starpvalodas fāzes uz mērḳvalodu. 